\title{
SELECTIVE HYDROGENOLYSIS OF GLYCEROL TO PROPYLENE GLYCOL IN A CONTINUOUS FLOW TRICKLE BED REACTOR USING COPPER CHROMITE AND Cu/Al $\mathrm{O}_{3}$ CATALYSTS
}

\author{
Jorge Sepúlveda ${ }^{\mathrm{a}}$, Debora Manuale ${ }^{\mathrm{a}}$, Lucia Santiago ${ }^{\mathrm{a}}$, Nicolás Carrara ${ }^{\mathrm{a}}$, Gerardo Torres ${ }^{\mathrm{a}}$ Carlos Vera $^{\mathrm{a}}$, Maraisa Goncalves ${ }^{\mathrm{b}, \mathrm{c}}$, \\ Wagner Carvalho ${ }^{\mathrm{b}}$ and Dalmo Mandelli ${ }^{\mathrm{b}, *}$ \\ anstituto de Investigaciones en Catálisis y Petroquímica - INCAPE (UNL-CONICET), Santiago del Estero 2654, 3000 Santa Fe, \\ Argentina \\ ${ }^{\mathrm{b}}$ Centro de Ciencias Naturais e Humanas, Universidade Federal do ABC, Rua Santa Adelia, 166, 09210-070 Santo Andre - SP, Brasil \\ 'Universidade Federal de São Paulo, Instituto de Ciencias e Tecnologia, Rua Talim 330, São Jose dos Campos - SP, Brasil
}

Recebido em 26/07/2016; aceito em 26/12/2016; publicado na web em 14/02/2017

\begin{abstract}
SELECTIVE HYDROGENOLYSIS OF GLYCEROL TO PROPYLENE GLYCOL IN A CONTINUOUS FLOW TRICKLE BED REACTOR USING COPPER CHROMITE AND Cu/ $\mathrm{Al}_{2} \mathrm{O}_{3}$ CATALYSTS. The glycerol hydrogenolysis reaction was performed in a continuous flow trickle bed reactor using a water glycerol feed and both copper chromite and $\mathrm{Cu} / \mathrm{Al}_{2} \mathrm{O}_{3}$ catalysts. The commercial copper chromite had a higher activity than the laboratory prepared $\mathrm{Cu} / \mathrm{Al}_{2} \mathrm{O}_{3}$ and was used for most of the tests. Propylene glycol was the main product with both catalysts, acetol being the main by-product. It was found that temperature is the main variable influencing the conversion of glycerol. When the state of the glycerol-water reactant mixture was completely liquid, at temperatures lower than $190{ }^{\circ} \mathrm{C}$, conversion was low and deactivation was observed. At reaction temperatures of $210-230{ }^{\circ} \mathrm{C}$ the conversion of glycerol was complete and the selectivity to propylene glycol was stable at about 60-80\% all throughout the reaction time span of $10 \mathrm{~h}$, regardless of the hydrogen pressure level ( 1 to $20 \mathrm{~atm}$ ). These optimal values could not be improved significantly by using other different reaction conditions or increasing the catalyst acidity. At higher temperatures $\left(245-250{ }^{\circ} \mathrm{C}\right)$ the conversion was also $100 \%$. Under reaction conditions at which copper chromite suffered deactivation, light by-products and surface deposits were formed. The deposits could be completely burned at $250^{\circ} \mathrm{C}$ and the catalyst activity fully recovered.
\end{abstract}

Keywords: hydrogenolysis; copper chromite; glycerol conversion.

\section{INTRODUCTION}

The hydrogenolysis of glycerol to 1,2 propanediol (propylene glycol) and hydroxyacetone (acetol) is an important reaction from academic and industrial points of view. Many catalysts have been tried and the reaction has been performed both in the liquid and the vapor phase. ${ }^{1}$ Glycerol can be dehydrated to acrolein over acidic catalysts such as zeolites, heteropolyacids or sulfuric acid. Also, the glycerol can be dehydrated to acetol, e.g. over metal copper catalysts. In the presence of hydrogen however, glycerol can undergo hydrogenolysis to 1,2 and 1,3-propanediol. Copper containing catalysts of different composition are good catalysts for this purpose because of their poor hydrogenolytic activity toward $\mathrm{C}-\mathrm{C}$ bonds and their efficient activity for hydrogenation or dehydrogenation of the $\mathrm{C}-\mathrm{O}$ bond., ${ }^{2,3}$

Most of literature works indicate that the system efficiency is highly determined by the catalyst type, temperature, hydrogen pressure, residence time and glycerol content of the aqueous solution used as feed.

Copper-chromite has been identified as the most effective catalyst for the hydrogenolysis of glycerol to propylene glycol in batch systems. Dasari and coworkers found that at mild reaction conditions of $200{ }^{\circ} \mathrm{C}$ and $14 \mathrm{~atm}$ of hydrogen pressure and $80 \%$ glycerol aqueous solution yielded a $55 \%$ glycerol conversion and selectivity to propylene glycol of $85 \%$. At similar reaction conditions, but using a $5 \% \mathrm{Pd} /$ carbon catalyst, the conversion was only $5 \%$ and the selectivity $72 \% .{ }^{2} \mathrm{Zhou}$ and coworkers used a $\mathrm{Cu}-\mathrm{ZnO}-\mathrm{Al}_{2} \mathrm{O}_{3}$ catalyst in a reaction at $220{ }^{\circ} \mathrm{C}$ and $40 \mathrm{~atm}$ of hydrogen pressure and the selectivity to propylene glycol reached was 72-94 depending on the $\mathrm{Cu}: \mathrm{Zn}: \mathrm{Al}$ ratios of the catalyst. ${ }^{4}$ Yuan and coworkers reported the use of $\mathrm{Cu} /$

*e-mail: dalmo.mandelli@ufabc.edu.br
$\mathrm{MgO}$ at $30 \mathrm{~atm}$ and $180{ }^{\circ} \mathrm{C}$ with the conversion of glycerol varying between 22 to $82 \%$ and selectivity between 87 and $96 \% .{ }^{5} \mathrm{Ni}-\mathrm{Ce} / \mathrm{C}$ was also used in the reaction at $50 \mathrm{~atm}$ hydrogen pressure and $200{ }^{\circ} \mathrm{C}$. The conversion under these conditions was $90 \%$ and the selectivity to propylene glycol was $66 \% .{ }^{6}$ With $\mathrm{CuO} / \mathrm{SiO}_{2}$ at $180{ }^{\circ} \mathrm{C}$ and $80 \mathrm{~atm}$ hydrogen pressure, the selectivity to propylene glycol was reported to be $90 \%$ and the conversion $25-30 \% .^{7}$ Some authors have performed the hydrogenolysis of glycerol in two steps and over copper catalysts. ${ }^{8}$ Some others have used acid materials as co-catalysts. For example reports exist on the use of several catalysts such as ion-exchange resins combined with $\mathrm{Ru} / \mathrm{C}, \mathrm{Ru} / \mathrm{C}$ with niobia, 12-tungstophosphoric acid (TPA) supported on zirconia, $\mathrm{HZSM} 5$ and $\mathrm{Cu} / \mathrm{Al}_{2} \mathrm{O}_{3}{ }^{9-13}$

The objective of this work was to study the influence of some reaction conditions on the activity, selectivity and stability of copper chromite and $\mathrm{Cu} / \mathrm{Al}_{2} \mathrm{O}_{3}$ catalysts in the glycerol hydrogenolysis reaction. The reactions were performed in a packed trickle-bed reactor at conditions close to real industrial ones.

\section{EXPERIMENTAL PART}

\section{Catalysts materials}

The copper chromite catalyst had a reported structure of copper Chromite and was supplied by Harshaw (CU-1808 T, density $1.1 \mathrm{gcm}^{-3}, \mathrm{Cu}$ content $\left.35 \%\right) .{ }^{14} \mathrm{~A} \mathrm{Cu} / \mathrm{Al}_{2} \mathrm{O}_{3}$ catalyst was prepared in the laboratory by impregnation of an alumina support. This was a commercial high-purity $\gamma$-alumina (Cyanamid Ketjen CK 300). Main impurities were $\mathrm{Na}$ (5 ppm), Fe (150 ppm) and S (50 ppm). The extruded alumina pellets were ground and sieved and the 35-80 mesh fraction was separated and calcined in air $\left(3 \mathrm{~h}\right.$ at $\left.650{ }^{\circ} \mathrm{C}\right)$. The specific surface area of this support was $180 \mathrm{~m}^{2} \mathrm{~g}^{-1}$, the pore volume 
$0.49 \mathrm{~cm}^{3} \mathrm{~g}^{-1}$ and the average pore radius $5.4 \mathrm{~nm}$.

Copper was incorporated into the alumina by incipient wetness impregnation with a $\mathrm{Cu}\left(\mathrm{NO}_{3}\right)_{2}$ aqueous solution. The concentration and volume of the impregnating solution were adjusted in order to give a final copper content of $13 \%, 25 \%$ and $44 \%$ in the final catalyst. However, the materials with lower copper content (13\%) showed better catalyst activity than others materials, with higher selectivity to 1,2-PDO. Therefore, in this work, are only presented results with $13 \%$ of copper content.

\section{Catalysts characterization}

The crystalline structure of the catalyst was assessed by X-ray diffraction. Spectra were recorded in a Shimadzu XD-1 equipment, using $\mathrm{CuK}$ radiation filtered with $\mathrm{Ni}$. Temperature programmed oxidation (TPO) tests were performed in order to characterize the surface carbon deposits formed during the reaction. A continuous flow of a $\mathrm{He}: \mathrm{O}_{2}(5 \%)$ mixture was passed over the catalyst, while first keeping the temperature at $250{ }^{\circ} \mathrm{C}$ for $16 \mathrm{~min}$ and then heating at a rate of $16{ }^{\circ} \mathrm{C} \mathrm{m^{-1 }}$. Oxidation products $\left(\mathrm{CO}, \mathrm{CO}_{2}\right)$ were sent to a methanation reactor loaded with a Ni/kieselghur catalyst, and then to a flame ionization detector. ${ }^{15}$ The FID signal was continuously recorded in a computer. The amount and strength of the acid sites were assessed by temperature programmed desorption of pyridine. The samples were first immersed in an excess volume of pyridine (Merck, 99\%) at room temperature for $6 \mathrm{~h}$. Then they were filtered and dried in air in an open vial at room temperature and under a fume hood. The samples were then placed in a quartz microreactor and stabilized in $\mathrm{N}_{2}$ for $1 \mathrm{~h}$ at $100{ }^{\circ} \mathrm{C}$ and heated from this temperature to $650{ }^{\circ} \mathrm{C}$ at $10{ }^{\circ} \mathrm{C} \mathrm{min}^{-1}$. The desorbed products were continuously analyzed in a FID detector. The specific surface area was measured by means of nitrogen adsorption at $-196{ }^{\circ} \mathrm{C}$ in a Micromeritics Accusorb 2100E.

\section{Glycerol conversion reactions}

The reaction was performed in a trickle-bed reactor. The scheme is showed in Figure 1.

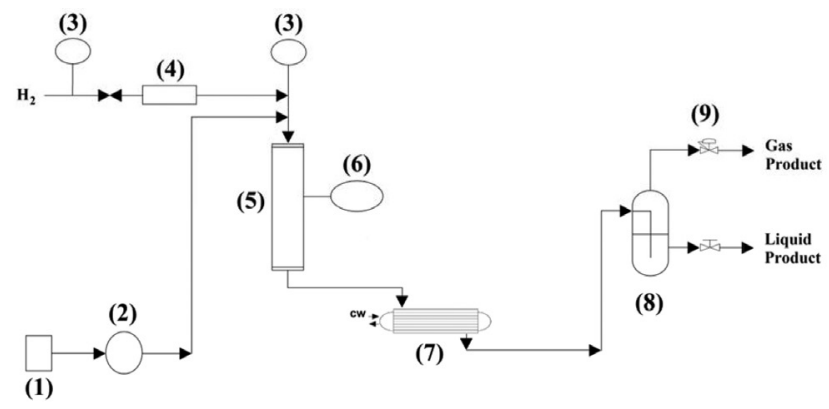

Figure 1. Scheme of the reaction equipment. (1) Liquid feedstock reservoir; (2) High pressure metering pump; (3) Manometer; (4) Mass flow controller; (5) Reactor and furnace; (6) Temperature controller and display; (7) Cooler/ condenser; (8) High pressure gas-liquid separator; (9) Backpressure regulator. CW: cooling water

The catalyst was placed over a quartz wool plug placed in the middle of the reactor. The catalyst was first reduced in situ at $250{ }^{\circ} \mathrm{C}$ in hydrogen for $1 \mathrm{~h}$. Then an aqueous solution of glycerol of 25 or $80 \%$ mass concentration was fed to the reactor in a down flow fashion at flowrate values of $4.8 \mathrm{~cm}^{3} \mathrm{~h}^{-1}$ to $18 \mathrm{~cm}^{3} \mathrm{~h}^{-1}$. Hydrogen was fed to the reactor by means of a Cole-Parmer mass flow controller $\left(48 \mathrm{ml} \mathrm{min}^{-1}\right)$ and the pressure was regulated at 1, 5, 18 and $20 \mathrm{~atm}$ with a Swagelok spring loaded backpressure controller. The reaction products were cooled down in a condenser and the gas and liquid products were separated in a pressurized gas-liquid separator vessel upstream the backpressure controller.

In each catalytic test, 2 and $4 \mathrm{~g}$ of catalyst (35-80 mesh of particle size) were used, and the temperature was varied between 190 and $250{ }^{\circ} \mathrm{C}$. The reaction products were sampled periodically and analyzed off-line in a Shimadzu 2014 gas chromatograph equipped with a flame ionization detector and a capillary column (J\&W INNOWax $19091 \mathrm{~N}-213,30 \mathrm{~m}$ length, $0.25 \mathrm{~mm}$ ID, 0.5 micron film thickness).

\section{RESULTS AND DISCUSSION}

\section{Catalyst characterization}

The structure of copper chromite was confirmed by means of $\mathrm{X}$-ray diffraction. X-ray diffractograms can be seen in Figure 2. The diffractograms of the material reduced at $250{ }^{\circ} \mathrm{C}$, before and after the reaction, presented no differences indicating that no changes in the crystal habitat or the degree of crystallinity occurred during calcination or reaction. Peaks due to metallic copper were found at $2 \theta=43^{\circ}, 51^{\circ}$ and $75^{\circ}$. A peak at $36.5^{\circ}$ due to the Delafasite phase $\left(\mathrm{CuCrO}_{2}\right)$ was found and a peak at $26.5^{\circ}$ was addressed to carbon, possibly related to the decomposition of the catalyst binder during calcinations. ${ }^{16,17}$

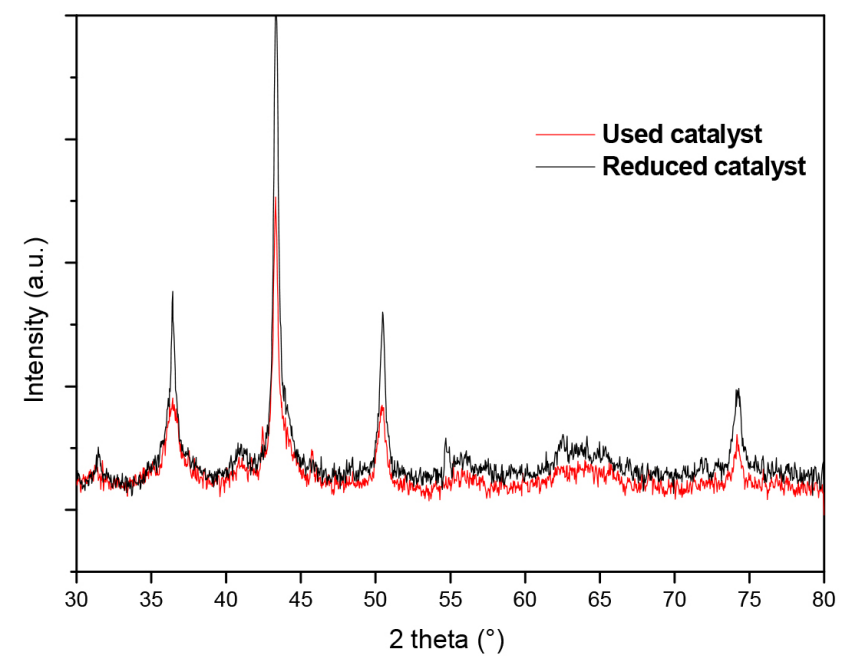

Figure 2. X-ray diffraction results of copper chromite catalyst reduce at $250{ }^{\circ} \mathrm{C}$

Pyridine thermal desorption was used to assess the concentration and strength of the surface acid sites of the catalysts. ${ }^{18}$

Total acidity was calculated from the total area of the Temperature programmed desorption (TPD) trace. Sites were classified into weak acid sites (desorbing between $150-300{ }^{\circ} \mathrm{C}$ ), mild acid sites (desorbing between $300-500{ }^{\circ} \mathrm{C}$ ) and strong acid sites (desorbing at temperatures higher than $500{ }^{\circ} \mathrm{C}$ ). Copper chromite had a total amount of acid sites of $0.31 \mathrm{mmol} \mathrm{g}^{-1}$. This is similar to the values reported by Mane et al. ${ }^{19}$ for copper chromite and by Romero et al.,${ }^{20}$ both using ammonia TPD. Distribution of strength was concentrated on mild acidity (66\%), the rest being weak (29\%) and strong (5\%). In the case of the pure alumina support the total acidity was $0.23 \mathrm{mmol} \mathrm{g}^{-1}$. Most of the sites were weak ones (82\%) and mild ones (18\%). The amount of strong acid sites was negligible. Addition of copper to the alumina support mainly increased the concentration of mild acid sites. The total amount of acid sites was $0.28 \mathrm{mmol} \mathrm{g}^{-1}$, distributed into weak acid sites (22\%), mild acid sites $(72 \%)$ and strong acid sites (4\%). 


\section{Catalytic activity}

Hydrogenolysis of glycerol is known to be a bifunctional reaction. It has been shown that the first step is the dehydration of glycerol to acetol over an acid site. The second step would be the hydrogenation of acetol over a metal site. ${ }^{2}$ The dehydration of alcohols is favored at high temperatures and is catalyzed by acid sites. In the case of the dehydration of glycerol the reaction occurs between 160 and $320^{\circ} \mathrm{C}$. When strong solid acids (in the Hammet Ho range of $-8.2<$ Ho $<-3.0$ ) and temperatures higher than $260^{\circ} \mathrm{C}$ are used dehydration proceeds with the formation of acrolein, i.e. the $\mathrm{OH}$ group of the central carbon is removed. Lauriol-Garbay and coworkers reported dehydrated glycerol selectively to acrolein at $300{ }^{\circ} \mathrm{C}$ in the gas phase using a mixture of zirconium and niobium oxides as catalyst. ${ }^{18}$ Haider and coworkers dehydrated glycerol to acrolein at $270-300{ }^{\circ} \mathrm{C}$ using $\mathrm{Ru}$ heteropolyacid catalysts. ${ }^{21}$ The dehydration of glycerol at different temperature also reported by Jia and coworkers using a ZSM-5 catalysts at $320^{\circ} \mathrm{C}^{22}$ and Dalla Costa and coworkers using beta zeolite catalysts at $275^{\circ} \mathrm{C} .{ }^{23}$

When the objective is to form propylene glycol from glycerol the reaction conditions needed are less energic than those for acrolein or acetol formation. Copper chromite is the most studied catalyst. It has sufficient surface acid sites to catalyze the glycerol dehydration to acetol, ${ }^{24}$ and some works have indicated that the acidity of copper chromite is increased at higher chromium contents. ${ }^{25}$ Romero and coworkers measured the amount and strength of acid sites of copper chromite by ammonia TPD and found that the samples desorbed ammonia between $150-400{ }^{\circ} \mathrm{C} .{ }^{20}$ Using the same technique Mane and coworkers found that $60 \%$ of the ammonia desorbed between $200-400{ }^{\circ} \mathrm{C}$ and that $25 \%$ was desorbed from strong acid sites at higher temperatures. ${ }^{19}$ From these reports it can be inferred that acidity promoters and acid co-catalysts enhance the global reaction rate. ${ }^{26,27}$ Balaraju and coworkers report that there exists a linear relation between the total acidity of the solid acid catalysts and the glycerol conversion. The same authors found that at $180{ }^{\circ} \mathrm{C}$ and $60 \mathrm{~atm}$ hydrogen pressure the addition of niobia to a $\mathrm{Ru} / \mathrm{C}$ base catalyst of moderate acidity increases the total acidity and the resulting activity. ${ }^{12}$ Miyazawa and coworkers studied the hydrogenolysis of glycerol at $160{ }^{\circ} \mathrm{C}$ and $60 \mathrm{~atm}$ hydrogen pressure using an Amberlyst ionic exchange resin as co-catalyst. They found that the use of $\mathrm{Ru} / \mathrm{C}$ and this resin co-catalyst improved the conversion and selectivity to propylene glycol (60\% conversion, $11 \%$ selectivity to propylene glycol). The synergic effect between the metal and the acid support or acid co-catalyst was explained by Miyazawa, who proposed that acetol was formed as an intermediate on the acid sites. ${ }^{28,29}$

Figure 3 shows the results of catalytic activity at $220{ }^{\circ} \mathrm{C}$ and 18 atm of hydrogen pressure.

The conversion level was $100 \%$ throughout the whole reaction time (0-10 h). Though no activity changes were observed, selectivity changes were indeed detected. In Figure 3 it can be seen that the selectivity to propylene glycol (desired) at the beginning of the reaction is higher on $\mathrm{Cu} / \mathrm{Al}_{2} \mathrm{O}_{3}(90 \%)$ than on copper chromite $(70 \%)$. The selectivity of $\mathrm{Cu} / \mathrm{Al}_{2} \mathrm{O}_{3}$ to propylene glycol is reduced to $75 \%$ after $10 \mathrm{~h}$ but the selectivity on copper chromite is completely stable at $70 \%$. Acetol is almost the only other product and in this sense its selectivity variation is inverse to that of propylene glycol. The selectivity to acetol is much higher on $\mathrm{Cu} / \mathrm{Al}_{2} \mathrm{O}_{3}$ is low (4-8\%) during the reaction. On copper chromite the selectivity to acetol is stable at $30 \%$ throughout the entire run.

Other glycerol dehydration tests were performed using nitrogen as gas carrier instead of hydrogen. At $210{ }^{\circ} \mathrm{C}$ the copper chromite catalyst had a $5 \%$ yield for acetol while $\mathrm{Cu} / \mathrm{Al}_{2} \mathrm{O}_{3}$ had $8 \%$.

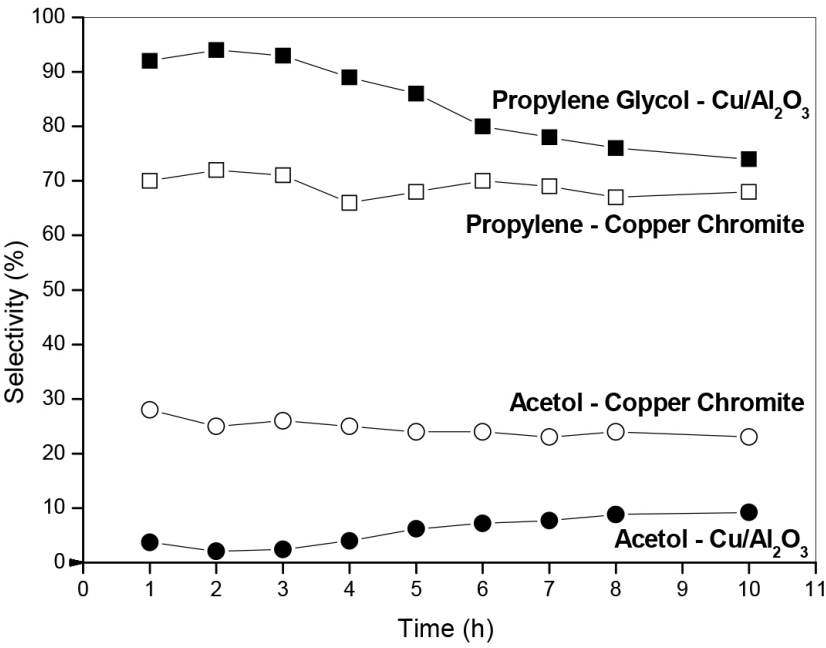

Figure 3. Selectivity to propylene glycol and acetol when using $\mathrm{Cu} / \mathrm{Al}_{2} \mathrm{O}_{3}$ and copper chromite at $220^{\circ} \mathrm{C}$ and 14 atm of total hydrogen pressure. The conversion of glycerol is kept at $100 \%$ during the reaction time

\section{Influence of the reaction temperature}

Recalling that the hydrogenolysis of glycerol proceeds by two consecutive steps, dehydration and hydrogenation, it can be inferred that the dehydration is favored at higher temperatures while hydrogenation is not. For dehydration there is mainly a kinetic effect due to the relatively high activation energy. In the case of dehydrogenation there is a thermodynamic effect mainly related to the exothermicity of the reaction. Dehydrogenation would be favored at low temperatures and high hydrogen pressure. There is, in consequence, an optimal temperature at which dehydration proceeds with a non-negligible rate and at which dehydrogenation is not very inhibited. ${ }^{8,30}$

The conversion of glycerol over copper chromite was first studied as a function of temperature at 18 atm of hydrogen pressure (see Figure 4).

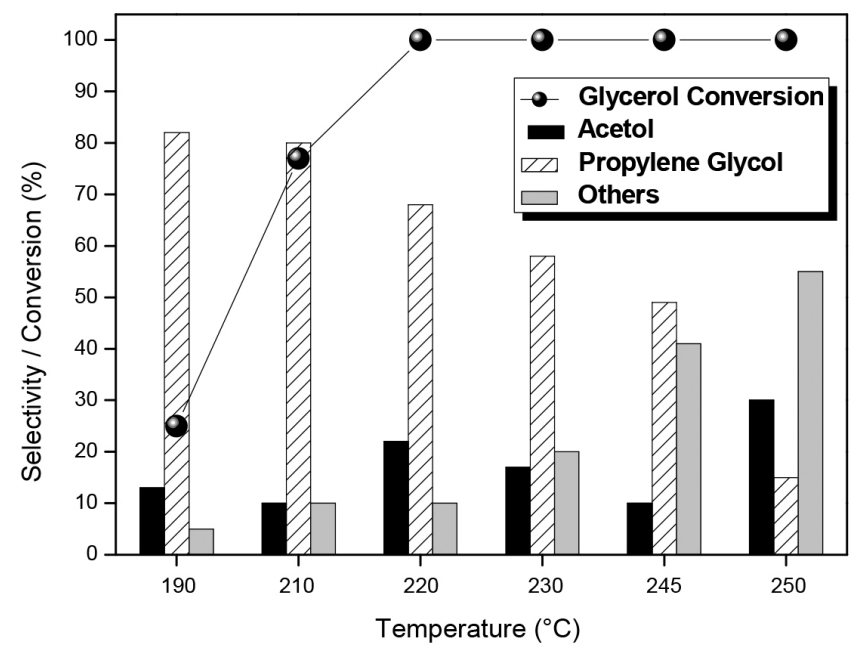

Figure 4. Reaction of glycerol (25\%, aqueous solution) catalyzed by copper chromite at different temperatures. Glycerol conversion $(X)$ and selectivity $(S)$ to different products at $10 \mathrm{~h}$ of time-on-stream and 18 atm hydrogen pressure

At $190{ }^{\circ} \mathrm{C}$ and 18 atm hydrogen pressure a $25 \%$ conversion of glycerol and $79 \%$ selectivity to propylene glycol were found. When the reaction temperature was raised to $210{ }^{\circ} \mathrm{C}$ a great increase of conversion is seen, though the selectivity to propylene glycol remains constant. The activity, selectivity and stability of the catalyst are 
strongly dependent on the physical state of the reactant and products under the reaction conditions.

Table 1 summarizes the properties of the liquid and gas phases in the reactor.

Table 1. Physical state of the feedstock solution (25\% glycerol in water) as a function of pressure and temperature

\begin{tabular}{ccccc}
\hline \multirow{2}{*}{$\begin{array}{c}\text { Temperature, } \\
{ }^{\circ} \mathrm{C}\end{array}$} & \multicolumn{2}{c}{ Pressure $=1 \mathrm{~atm}$} & \multicolumn{2}{c}{ Pressure $=18 \mathrm{~atm}$} \\
\cline { 2 - 5 } & $\begin{array}{c}\text { Vapor molar } \\
\text { fraction }\end{array}$ & State & $\begin{array}{c}\text { Vapor molar } \\
\text { fraction }\end{array}$ & State \\
\hline 190 & 0.95 & Liquid-Vapor & n.d. & Líquid \\
220 & 1.00 & Vapor & 0.72 & Liquid-Vapor \\
245 & 1.00 & Vapor & 0.88 & Liquid-Vapor \\
\hline
\end{tabular}

n.d.: not detectable.

The physical (liquid or gas) states were inferred from vapor pressure equilibrium data for the pure compounds, as calculated with the HySys software (NRTL model). The increase in conversion upon the increase in temperature (to $220^{\circ} \mathrm{C}$ ) can be due to change of state of the water-glycerol reacting mixture from the liquid to the vapor state. In the vapor state the accessibility of the catalyst surface is increased due to the higher diffusivity of the reactants in the vapor phase.

In the $220-245^{\circ} \mathrm{C}$ temperature range no change in the physical state of the reaction mixture is expected and both molecules are in the vapor state. At the reaction temperature of $245^{\circ} \mathrm{C}$ the conversion of glycerol is stable at $100 \%$ but extensive changes in selectivity, as a function of reaction time, can be detected. The results in Figure 5 indicate that during the run the selectivity to propylene glycol is drastically reduced while the production of 1-propanol is increased to almost $40 \%$. The selectivity to acetol does not change. Nakagawa and coworkers proposed a route in which propylene glycol form 1-propanol, a product of over-hydrogenolysis. ${ }^{31}$

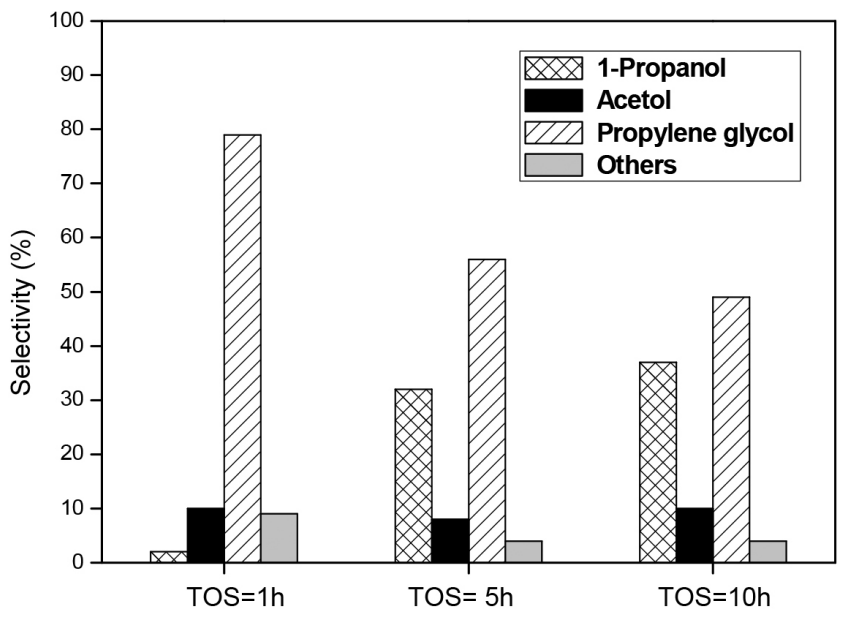

Figure 5. Reaction of glycerol (25\%, aqueous solution) catalyzed by copper chromite at $245^{\circ} \mathrm{C}$. Selectivity to different reaction products at 18 atm hydrogen pressure and three different values of time-on-stream (TOS)

\section{Hydrogen pressure effects}

An inspection of the literature indicates that the influence of hydrogen pressure can be very different depending on the values of the rest of the reaction variables. For example at $240{ }^{\circ} \mathrm{C}$ and using a copper catalyst an almost linear relation is found between hydrogen pressure and initial conversion of glycerol. ${ }^{32}$ In attention to these reported results a temperature range $\left(190,220\right.$ and $\left.245^{\circ} \mathrm{C}\right)$ was chosen in order to study the effect of the hydrogen pressure.

Figure 6 contains the results of catalytic activity and selectivity as a function of hydrogen pressure (1 and $18 \mathrm{~atm})$, at $220^{\circ} \mathrm{C}$, a time-on-stream of $10 \mathrm{~h}$ and two values of space velocity (WHSV of 0.7 and $\left.2.1 \mathrm{~h}^{-1}\right)$.

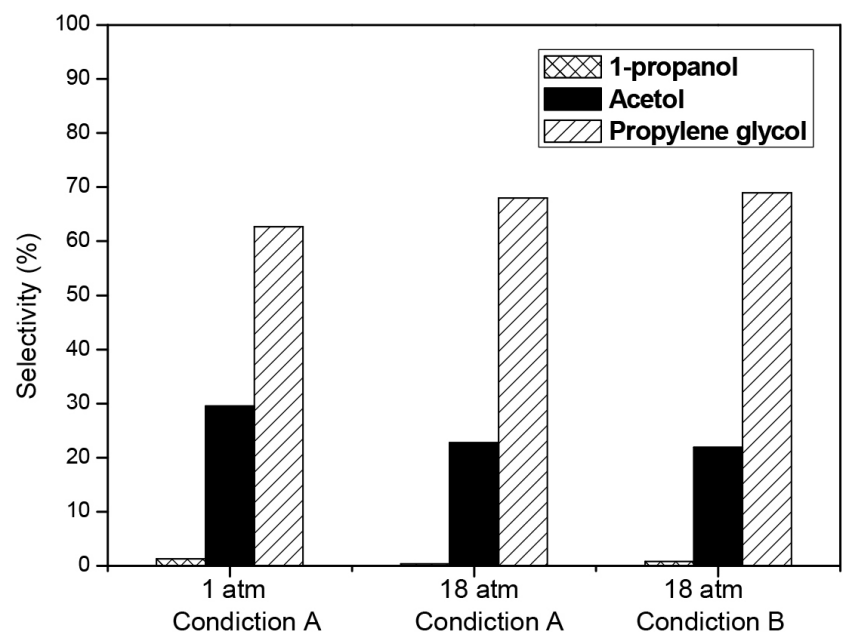

Figure 6. Reaction of glycerol catalyzed by at $220^{\circ} \mathrm{C}$ and two different conditions: A) $25 \%$ glycerol feed, $4.8 \mathrm{~mL} \mathrm{~h}^{-1}$ feed flowrate, $2 \mathrm{~g}$ of catalyst; $B$ ) $80 \%$ glycerol feed, $9 \mathrm{~mL} \mathrm{~h}^{-1}$ feed flowrate, $4 \mathrm{~g}$ of catalyst). Selectivity to the main products at $10 \mathrm{~h}$ of time-on-stream and two values of hydrogen pressure

These results can be considered as representative of the activity pattern which was almost the same to others values. The conversion of glycerol was always complete $(100 \%)$ either at the beginning of the reaction or after 10 hours. The main products were propylene glycol and acetol, with recorded selectivities of $63-68 \%$ and $0.3-$ $1.3 \%$, respectively. The selectivity to propylene glycol was improved by increasing the hydrogen pressure while the opposite occurred with acetol. This confirms that acetol is an intermediate product of the reaction; i.e. glycerol is dehydrated to acetol and then acetol is hydrogenated to propylene glycol. ${ }^{28}$

The results at $220{ }^{\circ} \mathrm{C}$ only indicate a mild effect of hydrogen pressure, improving the selectivity to propylene glycol. The effect of hydrogen is not to sustain the activity, since total conversion can be seen at widely different pressure conditions. With respect to the physical state of the reacting mixture, this is not greatly changed by increasing the pressure. Calculations indicate that at $1 \mathrm{~atm}$ the reacting mixture is $100 \%$ in the vapor state and that at 18 atm the mixture is $72 \%$ vaporized.

Results indicating the influence of hydrogen pressure at a reaction temperature of $190^{\circ} \mathrm{C}$ can be seen in Figure 7.

In these conditions high deactivation of the catalyst can be seen. This is be due to the low temperature leading to a reacting mixture mainly in the liquid state. At $190^{\circ} \mathrm{C}$ the steam would also not be able to exert an effective stripping action of the glycerol reactant and the reaction products which then would not be able to desorb from the catalyst surface. It can also be seen that deactivation is more important at high pressure. At 18 atm and $3 \mathrm{~h}$ of time-on-stream only $20 \%$ of the glycerol was converted although the selectivity to propylene glycol was about $80 \%$. At a total pressure of 1 atm deactivation was less severe and after $6 \mathrm{~h}$ of time-on-stream the reaction still had a meaningful conversion level. The selectivity to propylene glycol, however, dropped to $20 \%$ after $5 \mathrm{~h}$ of time-on-stream. According to Table 1 at $190{ }^{\circ} \mathrm{C}$ and 18 atm total pressure glycerol is totally in the liquid phase, while at $1 \mathrm{~atm} 95 \%$ is in the vapor phase. Therefore 


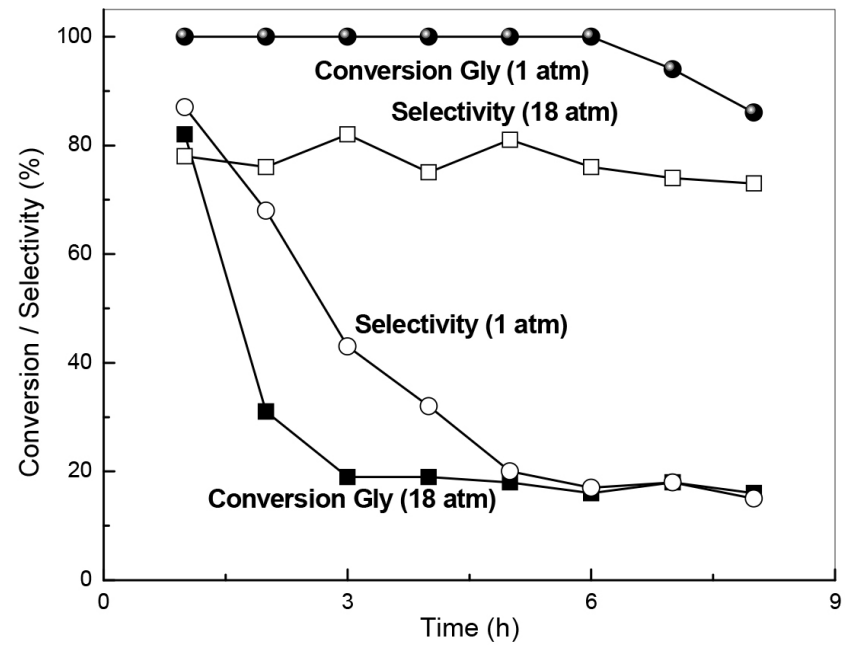

Figure 7. Hydrogenolysis of glycerol at $190{ }^{\circ} \mathrm{C}$. Conversion and selectivity to propylene glycol as a function of time-on-stream and system pressure. (๑) Glycerol conversion, $1 \mathrm{~atm}$. (О) Selectivity, $1 \mathrm{~atm}$. (口) Glycerol conversion, $18 \mathrm{~atm}$. ( $\square)$ Selectivity, $18 \mathrm{~atm}$

we assume that the main cause of deactivation and loss of selectivity is the fouling of the catalyst surface by compounds that cannot be desorbed due to the low reaction temperature.

Finally it can be seen that no 1-propanol can be found at $190{ }^{\circ} \mathrm{C}$ among the reaction products. This indicates that over-hydrogenolysis is an activated reaction that needs higher temperatures to proceed to a meaningful extent.

Figure 8 contains results of selectivity as a function of time-onstream, for the glycerol reaction at $245^{\circ} \mathrm{C}\left(\mathrm{WHSV}=0.71 \mathrm{~h}^{-1}\right)$.

The selectivity values were, however, different than those of the tests at 190 or $220^{\circ} \mathrm{C}$ (see Table 3, results at $18 \mathrm{~atm}$ ). It can be seen that at $245^{\circ} \mathrm{C}$ and $18 \mathrm{~atm}$ the selectivity to propylene glycol decreases from an initial value of $78 \%$ to a final value of $49 \%$ at $10 \mathrm{~h}$. The drop in selectivity to propylene glycol is accompanied by an increase in the selectivity to 1-propanol which, for example, is $37 \%$ at 10 hour.

At $245{ }^{\circ} \mathrm{C}$ and $1 \mathrm{~atm}$ of hydrogen pressure both selectivities (to acetol and propylene glycol) fall sharply at high of time-on-stream durations while the selectivity to 1-propanol increases until 65\%. This trend is easily explained by the previously proposed mechanism. Dehydration would be much favored by the high temperature and hydrogenation would be disfavored at low hydrogen pressures, thus, acetol production is favored over that of propylene glycol under these conditions.

The previous results would indicate that $220^{\circ} \mathrm{C}$ is the optimal reaction temperature. Results obtained at $220{ }^{\circ} \mathrm{C}, 18$ atm hydrogen pressure and different values of space velocity and reactant mixture composition can be seen in Table 2 .

The reaction conditions are quite unfavorable in the case of the $80 \%$ glycerol mixture because a higher glycerol flow rate reaction rate is needed for achieving a similar conversion value. Despite the

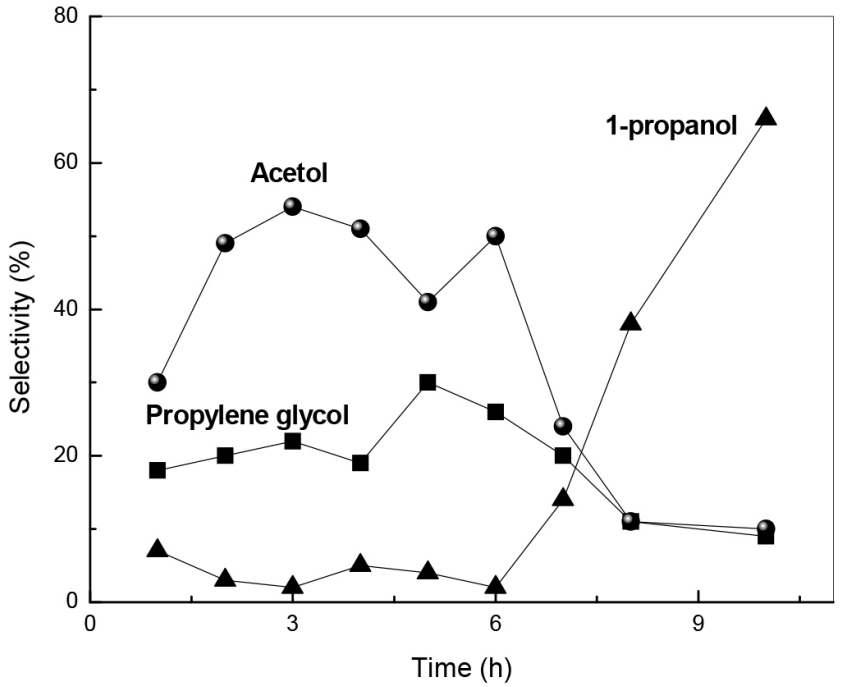

Figure 8. Selectivity of products of hydrogenolysis of glycerol catalyzed by copper chromite at $245^{\circ} \mathrm{C}$ and $1 \mathrm{~atm}$ hydrogen pressure. Conversion of glycerol was $100 \%$ all throughout the reaction. Glycerol concentration: $20 \%$

varying conditions of contact time and mixture composition, the selectivity results are very similar. In this sense, $220{ }^{\circ} \mathrm{C}$ and $18 \mathrm{~atm}$ hydrogen pressure seems to be a robust operation condition.

The results of this work can be compared with other reports on reactions performed in packed bed reactors. Abhari ${ }^{33}$ reacted pure glycerol (98\%) in a trickle bed reactor in the presence of a nickeltungsten catalyst under typical refining conditions of high temperature and pressure, yielding propanediols and propane. Glycerol was supplied at $0.65 \mathrm{~h}^{-1}$ (LHSV) and 155 bar. At $345{ }^{\circ} \mathrm{C}$ most of the feedstock was hydrotreated to propane though a liquid fraction (8.7 mass percentage of the feed) was also obtained. When lowering the temperature to $288{ }^{\circ} \mathrm{C}$, a liquid phase of $74.5 \%$ the mass of the feed (water product distilled off) was recovered and only minor amounts of gaseous propane were formed. The liquid phase contained 1,2-propanediol (74\%) and 1,3-propanediol (5\%). Casale and Gómez ${ }^{34}$ used a catalyst of $\mathrm{CuO}-\mathrm{ZnO}-\mathrm{Al}_{2} \mathrm{O}_{3}$ to react aqueous glycerol in a packed bed reactor. The hydrogen-to-glycerol molar ratio was $4: 1$ and the LHSV $1-1.6 \mathrm{~h}^{-1}$ and the temperature was $230-265{ }^{\circ} \mathrm{C}$. At these conditions conversion was $94.6-99.6 \%$ and selectivity to propylene glycol was 78-94\%. Schuster and Eggersdorfer ${ }^{35}$ used a catalyst containing $\mathrm{Cu}$, $\mathrm{Co}, \mathrm{Mn}$ and $\mathrm{Mo}$, packed in a tubular reactor, to react aqueous glycerol (86.5\%), at $295 \mathrm{bar}, 210-220^{\circ} \mathrm{C}, \mathrm{WHSV}=0.07 \mathrm{~h}^{-1}$. The products were 92\% 1,2-propanediol, $4.3 \%$ n-propanol, the rest being lower alcohols. Glycerol conversion was complete.

\section{Deactivation}

Temperature programmed oxidation tests were performed in order to determine whether carbonaceous deposits were formed that could

Table 2. Reaction of glycerol at $220^{\circ} \mathrm{C}$ and different values of hydrogen partial pressure (total pressure of $18 \mathrm{~atm}$ ). Selectivity at $10 \mathrm{~h}$ time-on-stream. Catalyst mass of $4 \mathrm{~g}$

\begin{tabular}{ccccc}
\hline $\begin{array}{c}\mathrm{H}_{2} \text { flow rate, } \\
\mathrm{mL} \mathrm{min}^{-1}\end{array}$ & $\begin{array}{c}\text { Glycerol flow rate, } \\
\mathrm{mL} \mathrm{h}^{-1}\end{array}$ & $\begin{array}{c}\text { Glycerol concentration, } \\
\text { mass } \%\end{array}$ & $\begin{array}{c}\mathrm{H}_{2} \text { partial pressure, } \\
\text { atm }\end{array}$ & $\begin{array}{c}\text { Selectivity to propylene } \\
\text { glycol, } \%\end{array}$ \\
\hline 48 & 4.8 & 25 & 15.4 & 70 \\
48 & 9.0 & 25 & 13.5 & 65 \\
120 & 4.8 & 25 & 16.8 & 73 \\
48 & 9.0 & 80 & 13.5 & 64 \\
120 & 9.0 & 80 & 15.9 & 65 \\
\hline
\end{tabular}


explain the deactivation detected under certain reaction conditions. In the case of copper catalysts some authors have reported that the metal function is deactivated by sintering, ${ }^{36,37}$ but this effect was not studied in this case.

The catalyst samples were collected after the reaction test and analyzed by TPO. The results can be seen in Figure 9 .

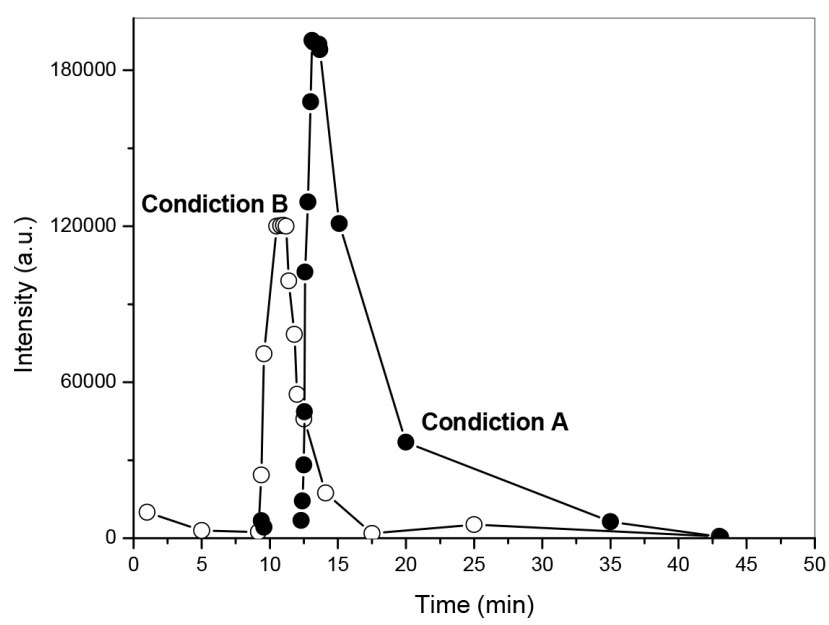

Figure 9. Analysis of carbon deposits by temperature programmed oxidation. A: Reaction at $220^{\circ} \mathrm{C}, 1 \mathrm{~atm} .10 \mathrm{~h}$ reaction time. B: Reaction at $220^{\circ} \mathrm{C}, 18$ atm, 10 h reaction time

The TPO traces have only one carbon deposit combustion peak, located at $280{ }^{\circ} \mathrm{C}$ in the case of Sample A (low pressure reaction) and at $260{ }^{\circ} \mathrm{C}$ in the case of Sample B (high pressure reaction). The area of the TPO trace of Sample B was almost one half that of Sample A. The coke contents were $3.9 \%$ and $2.6 \%$. This indicates that the coke deposits on Sample A had a higher degree of polymerization than those of Sample B. This is normal because the higher hydrogen pressure in the case of Sample B prevents the formation of heavy coke deposits. The mechanism could be one of hydrogen activation on $\mathrm{Cu}$ metal sites and hydrogenation of coke precursors. The low temperature of combustion would indicate that in both cases the carbon deposits have a very low molecular weight, probably corresponding to light polyglycerol oligomers. In this sense, no peaks at $500-550{ }^{\circ} \mathrm{C}$ due to the combustion of aromatic, graphitic carbon could be detected. ${ }^{38}$

Some samples were also examined by ESR (electron spin resonance), however $\mathrm{Cu}^{+1}$ and $\mathrm{Cu}^{+2}$ species could not be detected. Unpaired electrons could not be detected in the used copper chromite.

The carbon deposits were easily eliminated by stopping the injection of the glycerol solution and stripping with air at the reaction temperature for $30 \mathrm{~min}$. This indicates that, even in the case of catalytic activity decay, can be recovered by a simple regeneration procedure. One simple inspection of the catalyst particles with the naked eye indicated that they were dry, i.e. no liquid glycerol or any liquid products remained on the catalyst at the reaction temperature chosen, $220{ }^{\circ} \mathrm{C}$.

At $190{ }^{\circ} \mathrm{C}$ the catalysts taken from the reactor after $10 \mathrm{~h}$ and cooled down to room temperature were wet. Their analysis by TPO produced carbon combustion traces similar to those of Figure 6. The catalyst surface is expected to be covered by either glycerol or propylene glycol, since both have boiling points higher than $190^{\circ} \mathrm{C}$. At the reaction temperature of $245^{\circ} \mathrm{C}$ the catalyst after $10 \mathrm{~h}$ of reaction was dry.

\section{CONCLUSIONS}

The reaction of hydrogenolysis of glycerol to propylene glycol in the temperature range of $190-245{ }^{\circ} \mathrm{C}$ does not require strong acid sites. The main products are acetol and 1,2 propylene glycol.

Reaction temperature is the main variable affecting the activity, selectivity and stability of copper chromite catalysts for glycerol hydrogenolysis.

Catalytic activity and selectivity at a reaction temperature of $220{ }^{\circ} \mathrm{C}$ are not affected by the hydrogen pressure or the hydrogento-glycerol ratio. At this temperature the surface of the catalyst is essentially dry (free of non-desorbed reactants or products) and the selectivity to propylene glycol is $63-68 \%$.

At $190{ }^{\circ} \mathrm{C}$ the catalyst surface is covered by glycerol and its reaction products and hydrogen partial pressure becomes an important variable. The catalyst deactivates and the deactivation is enhanced at higher pressures. Selectivity to propylene glycol is about $80 \%$ at $18 \mathrm{~atm}$.

At $245^{\circ} \mathrm{C}$ hydrogen pressure has a positive influence on the selectivity to 1,2-propanodiol, being $50 \%$ at 18 atm and $10 \%$ at 1 atm at the end of the run. At this temperature the selectivity to 1-propanol is much favored (70\% at $1 \mathrm{~atm})$.

The TPO experiments indicate that at these reaction conditions (1-18 atm, $190-245^{\circ} \mathrm{C}$ ) no graphitized coke is formed on the surface of the copper chromite catalysts. Polyglycerol oligomers of low combustion temperature seem to be the prevailing species.

\section{ACKNOWLEDGEMENTS}

The authors thank the financial support of CAPES (Brazil) and MinCyT (Argentina) (CAPES/MINCyT 208/12) and FAPESP (2011/22264-4).

\section{REFERENCES}

1. Bienholz, A.; Hofmann, H.; Claus, P.; Appl. Catal. A 2011, 391, 153.

2. Dasari, M. A.; Kiatsimkul, P.; Sutterlin, W. R.; Suppes, G. J.; Appl. Catal. A 2005, 281, 225.

3. Montassier, C.; Giraud, D.; Barbier, J.; Stud. Surf. Sci. Catal. 1988, 41, 165.

4. Zhou, Z.; Li, X.; Zeng, T.; Hong W.; Cheng Z.; Yuan, W.; Chin. J. Chem. Eng. 2010, 18, 384.

5. Yuan, Z.; Wang, J.; Wang, L.; Xie, W.; Chen, P.; Hou, Z.; Bioresou. Technol. 2010, 101, 7088.

6. Yu, W.; Zhao, J.; Ma H.; Miao, H.; Song, Q.; Xu J.; Appl. Catal., A 2010, 383, 73 .

7. Huang, Z.; Cui, F.; Kang, H.; Chen, J.; Xia, C.; Appl. Catal., A 2009, 366, 288.

8. Sato, S.; Akiyama, M.; Takahashi, R.; Hara, T.; Inui, K.; Yokota, M.; Appl. Catal., A 2008, 347, 186.

9. Sun, D.; Yamada, Y.; Sato, S.; Ueda, W.; Appl. Catal., B 2016, 193, 75.

10. Liu, H.; Huang, Z.; Kang, H.; Xia, C.; Chen, J.; Chin. J. Catal. 2016, 37, 700 .

11. Soares, A. V. H.; Salazar, J. B.; Falcone, D. D.; Vasconcellos, F. A.; Davis, R. J.; Passos, F. B.; J. Mol. Catal. A: Chem. 2016, 415, 27.

12. Balaraju, M.; Rekha, V.; Sai Prasad, P. S.; Prabhavathi Devi, B.; Prasad, R. B. N.; Lingaiah, N.; Appl. Catal., A 2009, 354, 82.

13. Jia, Y.; Liu, H.; Chin. J. Catal. 2015, 36, 1552.

14. Rao, R.; Dandekar, A.; Baker, R. T. K.; Vannice, M. A.; J. Catal. 1997, $171,406$.

15. Fung, S. C.; Querini C.; J. Catal. 1992, 38, 240.

16. Deutsch, K. L.; Shanks, B. H.; J. Catal. 2012, 285, 235

17. Plyasova, L. M.; Solovyeva, L. P.; Krieger, T. A.; Makarova, O. V.; Yurieva, T. M.; J. Mol. Catal. A: Chem. 1996; 105, 61.

18. Lauriol-Garbay, P.; Millet, J.; Loridant, S.; Belliere-Baca, V.; Rey P.; J. Catal. 2011. 280, 68. 
19. Mane, R.; Ghalwadkar, A.; Hengne, A.; Suryawannshi, R.; Rode, C.; Catal. Today 2011, 164, 447.

20. Romero, A.; Santos, A.; Escrig, D.; Simon, E.; Appl. Catal., A 2011, 392, 19.

21. Haider, M. H.; Dummer, N. F.; Zhang, D.; Miedziak, P.; Davies, T. E.; Taylor, S. H.; J. Catal. 2012, 286, 206.

22. Jia, C-J.; Liu, Y.; Schmidt, W.; Lu, A-H.; Schüth, F.; J. Catal. 2010, 269 , 71.

23. Dalla Costa, B. O.; Peralta, M. A.; Querini, C. A.; Appl. Catal., A 2014, 472, 53 .

24. Chiu, C. W.; Dasari, M. A.; Suppes, G. J.; Sutterlin, W. R.; AIChE J. 2006, 52, 3543.

25. Johansson, L. E.; Lundin, S. T.; J. Am. Oil Chem. Soc. 1979, 56, 974.

26. Chaminand, J.; Djakovitch.; L.; Gallezot, P.; Marion, P.; Pinel, C.; Rosier, C.; Green Chem. 2004, 6, 359.

27. Alhanash, A., Kozhevnikova, E. F.; Kozhevnikov, I. V.; Catal. Lett. 2008, $120,307$.
28. Miyazawa, T.; Koso S.; Kunimori K.; Tomishige, K.; Appl. Catal., A 2007, 329, 30

29. Miyazawa, T.; Kusunoki, Y.; Kunimori, K.; Tonishige, K.; J. Catal. 2006, 240, 213.

30. Sato, S.; Akiyama, M.; Inui, K.; Yokota, M.; Chem. Lett. 2009, 38, 560.

31. Nakagawa, Y.; Ning, X.; Amada, Y.; Tomishige, K.; Appl. Catal., A 2012, 433, 128.

32. Sharma, R. V.; Kumar, P.; Dalai, A. K.; Appl. Catal., A. 2014, 477, 147.

33. Abhari, R.; US Pat. 8,058,484 2011.

34. Casale, B.; Gómez, A. M.; US Pat. 5,214,219 1993.

35. Schuster, L.; Eggersdorfer, M.; US Pat. 5,616,817 1997.

36. Vasiliadou, E. S.; Lemonidou, A. A.; Appl. Catal., A 2011, 396, 177.

37. Massa, M.; Andersson, A.; Finocchio, E.; Busca, G.; J. Catal. 2013, 307, 170.

38. Alvarez, W. E.; Kitiyanan, B.; Borgna, A.; Resasco D. E.; Carbon 2001, $39,547$. 